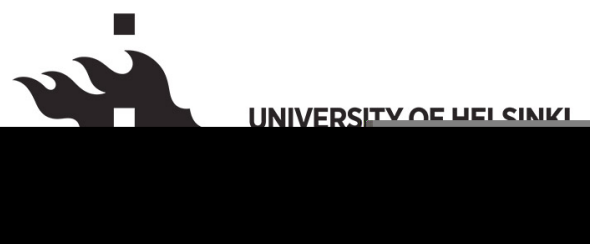

HELSINGIN YLIOPISTO

HELSINGFORS UNIVERSITET

UNIVERSITY OF HELSINKI 


\title{
Sick leave from work and the voting booth? A register-based study on health and turnout
}

Published as: Mikko Mattila \& Hanna Wass \& Hannu Lahtinen \& Pekka Martikainen (2018):

Sick leave from work and voting booth? A register-based study on health and turnout. Acta

Politica 53(3): 429-447.

\begin{abstract}
Previous studies show that people with poor health have a lower propensity to vote. With individual-level register data on sickness allowance episodes and voting in three Finnish elections, we address the following questions: 1) What degree of sickness allowance days negatively influences turnout? 2) Are sickness absences on election day more harmful than absences that occur before the elections? 3) What is the effect of cumulative sickness allowance spells before the elections over a period of several years? We use a threefold categorisation approach, which differentiates between immediate, short-term and long-term health effects on voting. The results show that multiple sickness allowance spells over several years are more strongly connected to turnout than health problems experienced only in the year prior to the elections. Falling ill at the time of the elections had no consistent additional negative relationship with voting. We suggest that the demobilising effects of immediate health problems are associated with tangible factors, while long-term effects are related to lowered levels of political efficacy, interest and social connectedness.
\end{abstract}




\section{Introduction}

A growing body of research has reported that those with poor health or disabilities are less likely to vote in elections than those in good health (e.g., Denny and Doyle 2007a, b; Gollust and Rahn 2015; Mattila et al. 2013; Pacheco and Fletcher 2015; Schur and Kruse 2000; Schur et al. 2015; Burden et al. 2017). These studies are highly topical as growing health-related disparities are becoming a major issue in many, if not most, developed countries. Differences in well-being are also increasing in universal welfare states (OECD 2013). In addition, the societal and political importance of health issues is likely to increase in the future due to ageing populations in most countries.

In spite of the increasing interest in the association between health and participation, little is known about the exact ways in which the two are related. While falling ill at the time of the elections could obviously constitute a tangible obstacle for accessing a polling station, this hardly represents the entire story. In terms of democratic equality, however, long-term sickness may have more severe consequences, such as declining motivation to follow politics, social isolation and fewer opportunities for political mobilisation.

In this study, we analyse how the timing, magnitude and accumulation of health problems are associated with turnout. On the basis of individual-level register data on sickness allowance episodes and voting from three Finnish elections, the following questions are addressed. First, what degree of sickness allowance days negatively influences turnout (magnitude)? Second, what is the role of the occurrence of sickness allowance episodes vis-à-vis elections (timing)? Are sickness absences on election day more harmful than absences that occur before the elections? Third, what is the effect of cumulative sickness allowance spells several years before the elections (accumulation)? For this purpose, we develop a threefold categorisation of health problems, differentiating between immediate, short-term and long-term health effects on voting.

The association between health and electoral participation may have substantial implications for the functioning of the representational process. A lower participation rate among citizens with poor health may lead to a situation where their interests and views are not taken into account in the political process to the same extent as those of more active citizens. Hence, our analysis is directly connected to the question of equal opportunity in political engagement. 
First, it demonstrates the relevance of personal health as a resource for political participation (Brady et al. 1998). Second, it demonstrates that non-voting is not always purely based on an LQGLYLGXDOIV RZQ FKRLFarIdDBUdis 2017). Instead, many disadvantages, such as poor health, are directly reflected in political participation. Third, understanding the special needs caused by health impairments is essential for inclusive democracy, as practices for political participation should be accessible for all kinds of citizens, regardless of their levels of resources (Young 2000).

Access to register data enables our study to avoid some of the methodological challenges faced by previous analyses with cross-sectional survey designs. These include the subjectivity and potential unreliability of the self-rated health measure, as well as the social desirability bias and memory failure regarding self-assessed electoral participation (e.g., Ansolabehere and Hersh 2012; Karp and Brockington 2005). An even more serious source of bias is related to the selfselection process in surveys. Individuals suffering from health problems are less likely to respond to surveys in the first place (Drivsholm et al. 2006). Likewise, those who are interested in politics are more inclined to answer questions about voting than their less interested counterparts (Sciarini and Goldberg 2016).

Taken together, our empirical results indicate that health disparities can be a significant factor in terms of producing inequalities in political participation. According to our analysis, longterm sickness absences are more strongly associated with a lower propensity towards voting than more short-term or acute health problems. Multiple sickness allowance spells over several years are more harmful in terms of voting than health problems only experienced in the year before the elections, or even during the actual voting period. In short: severity trumps timing.

\section{Temporal and accumulative components in the health-turnout association}

In previous studies, health has rarely been included among explanatory variables in the vast body of literature on electoral participation (Smets and van Ham 2013). The few studies conducted in Europe and the North America have reported a turnout difference of three to 12 percentage points (after controls) between those with poor and good self-assessed health (Denny and Doyle 2007a, b; Mattila et al. 2013; Pacheco and Fletcher 2015; Söderlund and Rapeli 2015; Couture and Breux forthcoming). Furthermore, the difference was found to be larger among older age groups (Mattila et al. 2013). 
From the perspective of democratic equality the issue is whether health constitutes a factor that causes a systematic bias in political participation. This question is by no means trivial because inequalities in preference articulation - in voting in our case - may lead to inequalities in political decision making (Jensen and van Kersbergen 2017, pp. 115-116), i.e., to the extent to which political elites respond to input from citizens with different levels of health. An unrepresentative political agenda, in turn, may have a feedback effect on participation motivations among citizens who suffer from health problems.

While previous studies have established an association between health and turnout, the examination of how health actually affects participation is still in its early stages. This is a serious deficit when the aim is to assess the overall challenge of health impairments on political equality. In this study, we suggest that evaluating the timing, magnitude and accumulation of health impairments represent an important dimension when answering this question. If tangible obstacles caused by acute sickness at the time of elections matter the most, there should be relatively little cause for concern. However, if accumulating health problems are related to a strong decline in turnout, the implications are more severe. In the latter case, differences in health may be a factor that inflicts permanent bias on participatory resources.

Our analysis is based on a threefold categorisation of health effects in order to operationalise their timing, magnitude and accumulation. While we refer to our three temporal and accumulative components as effects, strictly speaking, our empirical approach does not allow us to separate causal links between health and turnout. However, on a theoretical level, we are able to suggest mechanisms as to how these three components are related to turnout.

We refer to the most obvious implication that health may have on voting as the immediate effect of poor health. This measure captures health problems that are particularly acute on election day itself. In the case of sudden illness, for example, the required physical effort could become a tangible obstacle to political action. However, the effect should be fairly brief with no serious consequences for further political participation.

Yet, poor health may also have implications that are less closely tied to the exact timing of the illness or the elections. These potential non-immediate health effects can be further divided into two categories: short-term and long-term effects. Short-term effects are here defined as 
attributable to sickness absences in the year preceding election day. Sickness absences can lead to increased levels of stress and exhaustion and thus trigger concern with everyday issues, leading to decreased interest in politics.

Long-term or recurring health problems are often associated with increased stress and reduced levels of cognitive resources, physical mobility and social connectedness. People with severe and chronic health impairments may be less motivated to participate in politics because they feel less efficacious and because dealing with their condition requires a lot of mental effort, which can weaken their capacity to follow politics (Denny and Doyle 2007a; Schur et al. 2013, 93). In addition, serious chronic health conditions may lead to depression, which in turn is related to feelings of hopelessness and negative expectations about the future (Ojeda 2015). Naturally, depression could also be a chronic condition on its own. In addition, opportunities for political recruitment by voluntary associations, informal social networks and political organizations may be limited, as poor health decreases involvement in social activities and group meetings (Denny and Doyle 2007a; Schur et al. 2013, pp. 130-131). We measure these long-term effects by the number of years in which a person has received sickness allowances in the four years preceding the elections.

\section{Sickness absence as a health indicator}

Sick leave as a general measure of health has become increasingly popular in research fields, such as health, work and economics (Laaksonen et al. 2011; Piha 2013, p. 15). Sickness absences have been found to predict disability pension (Kivimäki et al. 2004; Labriola and Lund 2007), mortality (Ferrie et al. 2009; Vahtera et al. 2004) and various domains of health functioning (Laaksonen et al. 2011). A study by Kivimäki et al. (2003) further showed that sickness absences predict mortality even better than self-rated health or long-standing illness.

Here, we use sickness absence as a health indicator in order to measure the timing, magnitude and accumulation of health problems. To our knowledge, only one study has examined the connection between sickness absence and turnout. Bryngelson (2009) addressed the association between long-term sickness absence and non-voting in Sweden using register-based information on sickness absences, although the measure of electoral participation relied on survey data. In her longitudinal analysis, the effect of health was not statistically significant, possibly due to the low number of observations. Furthermore, self-reported sickness days and 
voting have been used in an analysis of political participation among senior citizens (Peterson 1987).

Compared to self-rated health, the most widely used single-item indicator of health in sociological medicine since the 1950s (Jylhä 2009, p. 307), our measure has both strengths and weaknesses. First, register-based information on the number of sickness allowance days is not sensitive to subjective experience. Second, it does no suffer from self-selection, which influences health measures in surveys as health profiles of the non-participants are typically worse than those of the participants (Drivsholm et al. 2006; Suominen et al. 2012). Third, sickness absences enable a more fine-JUDLQHGDVVHVVPHQWRIDQLQGLYLGXDOIV,KHDOWKFR whereas self-rated health only includes rather vague response catHJRULHVVXFKDV $\$$ YHU $\backslash J R G$. RU‡IDLU.

A number of shortcomings should also be mentioned (Dahle and Petersen 2005). Besides being only available in respect of the employed population (Piha 2013, p. 16), sickness absence may be influenced by factors that are not directly health-related, such as job position, insecurity and dissatisfaction, family situation, adverse life events and work-specific abstention practices and cultures (Labriola et al. 2006; Vahtera et al. 1997; Virtanen et al. 2008; Voss et al. 2004). For example, personal characteristics may affect the propensity to use the possibility for sickness absence: some people try to work regardless of their health problems, while others may try to take advantage of the situation to gain absence from work with even relatively harmless health impairments. It is difficult to control for such personal differences in a study like this. However, according to the epidemiological literature, the effect of potentially confounding issues is minimised when focusing on long-term absences (Kivimäki et al. 2003; Marmot et al. 1995; Vahtera et al. 2004). Since state-subsided sickness allowance is only available after a 10day waiting period, this study focuses on relatively long-term absences.

\section{Research design}

In Finland, sickness allowances are paid as compensation for loss of earnings caused by an illness. The incapacity to work needs to be certified by a medical doctor. In this respect, register-based information on sickness allowance days is a more valid indicator of serious health problems than the often-used self-assessed health measure (Svedberg et al. 2010). In practice, however, the Finnish sickness allowance system includes a 10-day waiting period. ${ }^{1}$ If 
an employee falls ill and is unable to work, he/she will receive a normal salary paid by the employer for the first 10 working days. After the 10-day period, the costs of illness are covered by the Social Insurance Institution (KELA).

To study the effect of sickness absences on turnout, we use individual-level register-based data from Finland. The data set, compiled by Statistics Finland (Permission TK-53-339-13), consists of an 11 per cent random sample of individuals permanently residing in Finland. Linked together via personal identification codes from various registers, the data contain LQIRUPDWLRQRQDQLQGLYLGXDOIVHGXFDWLRQRFFXSDWLRQADOFOhAKKE ISARLWLRQLQV income, as well as the number of days a person received sickness absence allowances.

While sickness allowances can be paid to employees, self-employed persons, unemployed job seekers and full-time students, our analyses concentrate solely on the employed population. Persons in old-age retirement, in military service or on disability pension are not included as they are not entitled to sickness allowance. Furthermore, we excluded students and unemployed persons. Although eligible, these groups have lower incentives when it comes to applying for absence allowances, since the amount of sickness allowance may be lower than or equal to study grants or unemployment benefits.

The use of work-based sickness allowances as the measure of health limits the analyses to the employed population. Since this group is in a favourable position in terms of both health and voting, namely, they are employed and within the age span in which the level of participation is high, our analysis can be considered as a rather stringent test for the health-turnout relationship. By excluding the non-employed population, such as students, homemakers and those with the most serious long-term health problems (on disability pension), our study population consists of a homogenous group of people with more or less similar motivations to vote. Finding an association between health and turnout among employed citizens would thus imply that a relationship, at least as strong as this, can be found among the entire population of eligible voters because those affected most by serious health problems are not included in our sample.

Altogether, our analyses cover 204,034 eligible voters for the 1999 parliamentary elections, 16,170 for the 2012 presidential elections and 32,768 for the 2012 municipal elections. In 2005 the sickness insurance law was changed so that to qualify for sickness absence allowances, a 
person must be between the ages of 16 and 67 and unfit for work on medical grounds. Before the change, the upper limit was 64 years (Blomgren 2016). Our sample includes eligible voters aged 18-64 years and employed at the end of the year preceding the elections. In order to guarantee comparability across elections we limited our analyses only to those under 65 years as this was the upper limit to qualify for sickness absence allowances during 1999 elections. ${ }^{2}$ Variations in the sample sizes are related to the fact that the information on voting is derived from two different sources. For the 1999 parliamentary elections, we use unique data compiled by Statistics Finland, which include almost the entire Finnish electorate, excluding the Åland Islands (for more information, see Martikainen et al. 2005). The data indicate whether or not a person voted in the 1999 elections. As these voting data practically cover all eligible voters in Finland, our sample for the 1999 elections is representative of the Finnish electorate.

More recent data were compiled from those electoral wards that took part in the electronic voter-register project, organized by the Ministry of Justice in the first round of the 2012 presidential elections and in the 2012 municipal elections. Municipalities could decide whether to participate in the project and which of their electoral wards were to be included. In these wards, electronic databases were used to register whether a person voted or not. The number of electoral wards using electronic registers was 115 out of 2,337 wards in the presidential elections held in January 2012. In the municipal elections held in October 2012, the number of electoral wards that used electronic registers had already almost doubled, covering 211 out of 2,265 wards $^{3}$. The total number of the eligible voters in these wards constituted 6.9 per cent of the electorate in the 2012 presidential and 13.6 per cent in the 2012 municipal elections. The data, administrated by the Ministry of Justice, were released to Statistics Finland after the elections. In Statistics Finland, the information on whether a person voted or not was linked to other data sets, via a personal identification number, as in the case of the 1999 elections.

Since random sampling was not used in choosing the wards that applied electronic voting registers, the representativeness of the data from the 2012 elections could be an issue. However, according to our diagnostics, the data are reasonably representative of the entire Finnish voting-age population. When compared to official voting records, municipal elections show almost the same turnout figures, whereas turnout in a sample concerning presidential elections is biased by 2.2 percentage points downwards. The distributions of gender, mother tongue, marital status and education also match reasonably well to official registers. Each category in each variable is biased by less than three percentage points. Although the number 
of observations was doubled from the time of the 2012 presidential elections to the 2012 municipal elections (from 12,757 to 26,123 ), the population in both samples is highly comparable with the entire electorate. This is also visible in Table A1 in the appendix, which compares our data from the 2012 presidential and municipal elections to the employed population in our complete data set (which is a random sample of the Finnish population). The youngest age groups seem to be slightly overrepresented, while other background variables show a very marginal bias.

The three elections included in the study substantially differ from each other in terms of their character. Municipal elections have the lowest level of saliency, demonstrated by a turnout of 58 per cent in 2012. Despite the decreased prerogatives of the president, presidential elections still gain the most interest among voters. In the first round of the 2012 presidential elections, turnout reached 73 per cent. Parliamentary elections lie somewhere between these two, with participation levels fluctuating at around 70 per cent in the past decade (68 per cent in 1999). Testing the strength of the health-turnout relationship in different kinds of elections allows us to evaluate the robustness of our results in different electoral contexts.

As explained earlier, we are looking at the relationship between turnout and sickness allowances from three time perspectives. First, we concentrate on the immediate effect of sickness on turnout. We define the immediate effect as the influence of either having a sickness allowance on election day (Sunday, 21 March 1999) or during the advance voting period. We then compare the effect of the election day allowance to that of having allowances on preceding Sundays from the beginning of the year 1999 ( $n=12$ Sundays). We also look at the effect of having at least one allowance day on a 12-day period from the beginning of the advance voting to the election day (10-21 March), compared to other 12-day periods before that in 1999 (starting from 28 December 1998, n=7 12-day periods). The idea is that, if the effect of being on sickness absence leave on election day does not significantly differ from the effect of being on sickness leave on any random Sunday before the election day, there cannot be an immediate health effect on voting. In this analysis, we use only the 1999 data, since the 2012 data do not include information on the exact dates of sickness allowances.

In the next step, our interest lies in the short- and long-term effects of health problems on turnout. We measure the short-term health problems as the number of days in which a person received sickness allowances in the year preceding the elections. The distribution of the 
number of sickness allowance days in a year is strongly positively skewed. Furthermore, our initial examination indicated that the relationship between voting and sickness allowance days does not appear to be linear. Thus, the number of sickness allowance days are categorised into five groups (0,1-7, 8-30, 31-90 and 91-300 days) to reflect the severity of health problems. As mentioned in the previous section, a 10-day waiting period needs to be added to these figures. This means, for example, that a person with one sickness allowance day has, in practice, been incapable of working for 11 days. As this categorisation, which is mainly based on the observed distribution, is admittedly somewhat arbitrary, other classifications were tested as well. The results did not change in any significant way.

Finally, the long-term effect of poor health is measured as the number of years during which a person has received at least one sickness absence allowance within the four-year period before the elections. Consequently, values in this variable range between 0 and 4 . This measure aims to tap the chronic character of health problems suffered over a period of several years. Accumulated sickness absence spells over several years are typically related to long-term chronic illnesses (Gjesdal and Bratberg 2003; Kivimäki et al. 2003). Although the measure is rather coarse, it appears capable of differentiating between individuals with temporary health problems and those with more chronic conditions. We also tested alternative specifications, such as a variable indicating the amount of sickness allowance days over the four preceding years, or a variable measuring the number of consecutive years a person received at least one sickness absence allowance, but these specifications did not substantially change the results.

Gender, age and age-squared are used as control variables as they are all strongly correlated with voting and health. Socio-economic status is measured with three established indicators. Education (basic, secondary, lower tertiary and higher tertiary) and occupational class, based on the latest occupational information available or, if unavailable, on the occupation of the head of the household (manual, lower non-manual, upper non-manual and self-employed) are ERWK JURXSHG LQWR IRXU FDWHJRULHV ,QFRPH TXDUWLOHV DUH IRUPHG RQ WKH EDVL annual income in state taxation with quartile cut points calculated from these data. All the socio-economic variables are measured using the information at the end of the previous year, except for occupational class for the 1999 elections, which was only available from 1995. Unfortunately, the register data at our disposal do not include geographical data on the voters (for example, the municipality or constituency they live in). As our data set is based on 
information from official registers, it does not contain the motivational variables that are often used in the analyses of turnout, such as party identification and ideological self-positioning.

We use a linear probability model in our empirical analyses, instead of the more commonly used logistic regression. The reason for this choice is that logistic regression does not enable us to compare coefficients between nested models or between elections (Mood 2010). Furthermore, the use of a linear model makes the interpretation of the coefficients easier, which in turn enables us to assess the magnitude of the effects of health in comparison to our control variables (such as education). We use the Huber-White method to estimate heteroscedasticityconsistent standard errors. However, to ensure the robustness of our results, we repeated the same analyses with logistic regression (the results are available in the online appendix), which produced almost identical results.

\section{Results}

We start the empirical section with an analysis of the immediate effect of health on turnout. As discussed previouslyWKHLPPHGLDWHKHDOW KIIMIGIfIILQHGDVDVSHOORIVLFNQHVVWKDWF the actual day of voting, or a 12-day period from the beginning of the advance voting period until election day. In the upper panel of Figure 1, the rightmost dot shows the impact of receiving a sickness allowance on election day (Sunday, $21 \mathrm{March}$ ), while the lower panel concerns the period from the beginning of advance voting until election day (10-21 March). Both are negatively associated with voting probability (5.9 percentage points lower for those receiving an allowance on election day, 5.3 points lower for at least one day of receiving an allowance during the 12-day period before elections). However, no consistent difference can be detected in the magnitude of the coefficient of having an allowance on any other Sunday or during any other 12-day period in 1999 before elections. These results indicate that the illness that occurred during the elections did not decrease voting propensity more than having health problems during other periods preceding election day. ${ }^{4}$

\section{FIGURE 1 HERE}

Next, we turn our analysis to the short- and long-term effects of sickness allowances using data from all three elections. ${ }^{5}$ Models 1 in Table 2 concentrate on the short-term effects and 
highlight the association between voting and the (categorised) number of sickness allowance days when adjusted for gender, age and age-squared, and gender. In Models 2, the long-term effect is included, with a variable measuring the number of years in which a person has received sickness allowances in the previous four years. Finally, in Models 3, the variables indicating an LQGLYLGX\$OHWeconomic position are included in the analysis. When interpreting the results, we rely on results from all models because the causal relationships between health and socio-economic position cannot be clearly and definitely established in advance. On the one hand, an individualys socio-economic position can affect his/her health. On the other hand, health problems may lead to lower levels of income, for instance (for a review, see Kröger et al. 2015). It should also be kept in mind that, compared to the overall population, our study population is relatively advantaged in terms of being employed and healthier.

Models 1 in Table 2 address the research question regarding the association between short-term health impairments and voting propensity. For all the three elections under investigation, the probability of voting declines when the number of sickness allowance days increases. Even a relatively small number of sickness allowance days in the year preceding the elections is associated with lower turnout, especially in the 1999 data. However, in general, the relationship is quite modest; one to seven allowance days is associated with a drop of two to four percentage points depending on electoral context. A more pronounced drop in turnout, namely, seven to nine points, occurs only among those individuals who had received sickness absence allowances for over 90 days.

\section{TABLE 1 HERE}

In Models 2, the long-term or cumulative effect of experiencing health problems during the previous four years is included. This variable is statistically significant in all models. Furthermore, the inclusion of the variable markedly influences the coefficients of the shortterm health variables, which become insignificant in the 2012 data. Similar results are seen in Models 3 with the socio-economic controls included, although now also the coefficients for the long-term health effect are clearly attenuated. For example, in the 1999 elections, one additional year with sickness absences was associated with a lower voting probability of 2.1 percentage points when the socio-economic controls are not included. Thus, the difference in voting probability between the extremes in this variable (an individual with no sickness 
absence and an individual with absences in all four years) is about eight percentage points $(=4 * 2.1)$. In the model with the socio-economic variables included, the difference is considerably smaller (about two percentage points). The respective differences in voting likelihood were 13 (Models 2) and six percentage points (Models 3) in the 2012 presidential elections and 11 and four percentage points in the 2012 municipal elections.

In general, turnout is strongly and positively associated with a high socio-economic position. The results suggest that education in particular, but also income and occupational class differences, are linked with larger differences in turnout than sickness allowance days. The finding that the association between poor health and low turnout is markedly diminished when DQLQGLYLGXDerffAconomic position is controlled for is not surprising as such. Previous VWXGLHV KDYH GHPRQVWUDWHG D VWURQJ DVVRFLDWLRQ ESHAWZZHH(DIQ LQGLYLGX position and turnout (e.g., Blais 2000; Martikainen et al. 2005; Wolfinger and Rosenstone 1980), as well as a link between socio-economic position and sickness absence (e.g., Piha 2013). This attenuated effect of health can be interpreted in two ways. On the one hand, part of the influence of socio-economic position on turnout may be mediated through poor health. In the group with most sickness allowance days, persons with a low educational level and low occupational class are overrepresented, whereas they are underrepresented among those with no sickness allowance spells (Piha et al. 2010). Health may thus work as a mechanism transforming the differences in socio-economic structures into inequalities in political participation (see Lahtinen et al. forthcoming). On the other hand, part of the effect of health SUREOHPV RQ YRWLQJ LV LQGHSHQGHQW RI DQolc@ectedromXdersition. While the association between a high socio-economic position and good health is well-established in previous studies, people may also suffer from health impairments regardless of their social standing.

\section{Conclusions}

In this study, we have observed that long-term sickness is more strongly associated with an LQGLYLGXDQOAgYpropensity than immediate or short-term health problems. Multiple sickness allowance spells over several years have more serious consequences than health problems that were only experienced during the year before the elections. This finding indicates that chronic health impairments tend to have a stronger negative relationship with voting than acute problems. The results did not show consistent support for the idea that falling ill at the time of 
the elections is connected to additionally decreased turnout, although this option could not entirely be ruled out.

These results help us to better understand the complicated connections between health problems and lower levels of political action. While immediate health problems are most probably associated with tangible factors (i.e., a temporarily weakened physical condition may cause a concrete obstacle for voting), long-term effects are more likely related to a decline in political efficacy, interest and social connectedness ${ }^{6}$. Our results suggest that temporary physical hindrances caused by acute health problems play only a small independent role in voting, if at all. This may be partly explained by contextual factors, especially the advance voting system in the Finnish elections and the facilitation of voting in hospitals and other nursing institutions (see, however, Wass et al. forthcoming)

This study focused on the employed population among which severe health problems are still relatively rare. In our sample, about 11 per cent had received sickness absence allowances in the year before the 1999 elections. For education and income, we observe larger point estimates of effect and also a gradient that runs through the whole population. It thus seems relatively clear that, for working aged, these social determinants of voting will have a larger total impact on turnout. However, for older ages, this balance is likely to tilt, while the total impact of health is likely to become more significant.

While our results show a relatively modest relationship between health and turnout, it is fruitful to interpret these within a wider frame of inequalities in political engagement. From the perspective of democratic equality, any kind of health-related obstacle is problematic, not only for groups suffering from poor health, but also for the entire political system as political participation should be accessible to all citizens. Health bias, whether small or substantial, should not be considered as solely personal challenge but also as a social issue. Accordingly, Schur et al. (2013, p. 237) argue that making full use of the talents of people with health problems might contribute to the economy and make democracy stronger by JXDUDQWHHLQJWKDWW KDWbieYddürRQHIV

In general, our results stress the importance of recognising the role of health as an important political resource and hence a vital element in electoral studies. Health can be one among many resources that produce cumulative advantages and disadvantages between individuals over the 
life course in political participation. Poor health is not merely a temporary inconvenience for voting in particular elections, as it may also contribute to permanent biases in participation. Many forms of health disparities are visible already early on in life, which are strongly linked to other indicators of social inequalities (Braveman and Barclay 2009). This conclusion is strengthened by the fact that our study included only employed persons, who on average have better health profiles than those outside the labour force. It is thus likely that a relationship, which is at least as strong as this, can be found among the entire population of eligible voters. On the other hand, it is also important to put our results into context. Although health and turnout in the polls are significantly related, the association is not as strong as, e.g., between education and turnout. Furthermore, for many individuals, the effect of health is most pronounced in the latter part of life, whereas the effects of education may be visible throughout LQGLYLGXDOVII HQWftedth@Lhatve finished their education. In this way, differences in education are even more likely to produce significant permanent inequalities in political participation than differences in health.

Nevertheless, low participation rates among citizens with poor health may, in turn, easily lead to a situation where their interests are not taken into account in political decision-making to the same extent as the preferences of more active citizens. As previous studies suggest, policy outcomes tend to reflect the interests of healthy citizens rather than their less healthy counterparts. This is especially problematic given that, as results from the US show, these two groups seem to differ markedly from each other in terms of policy preferences, particularly in the areas of social benefits, healthcare and employment policies (Gastil 2000; Henderson and Hillygus 2011; Robert and Booske 2011; Schur and Adya 2013). However, it is not selfevident that similar findings can be found in other contexts. Therefore, further research should study whether these results also hold in more egalitarian countries, such as Finland and the other Nordic welfare states.

Besides this substantive contribution, our study also implicates certain methodological advantages. The unique data set enabled us to avoid many of the potential hurdles associated with previous studies that relied on survey data. These include cross-sectional study designs, non-response, social desirability bias and other measurement problems that may influence the way respondents answer survey questions about their voting and health condition. Problems stemming from selection or non-response bias are potentially even more serious. At the same 
time, there are also limitations in our data. Survey-based data sets can address a larger range of factors; for example, many that are related to attitudes or behaviour.

Information on voting in several consecutive elections over a longer period would be needed to precisely gauge the long-term effects of health problems on voting. This would be especially useful for detecting the stage when deteriorating health will begin to interrupt participation, even among habitual voters. Furthermore, the data from the two elections held in 2012 were not based on a random sample of the entire Finnish electorate, which may weaken the reliability of the results. However, as there was no individual-level self-selection of the respondents, we have no reason to assume that the area-based sample selection systematically influenced our results.

In addition, our measure of sickness does not indicate the nature, type or severity of sickness, although long and recurrent sickness spells are likely to be associated with more serious health conditions. Sund et al. (2017) and Gollust and Rahn (2015) have shown that the lower likelihood of voting is associated with certain medical conditions, such as neurodegenerative brain diseases, while others, such as surviving cancer, can in fact increase voting. However, such detailed analysis was beyond the scope of this study and hence left to further inquiries. The logical next step is to focus on the diagnosis behind the sickness absence in order to differentiate more carefully between the related mechanisms. This would be particularly important since the results of this study suggest that short-term health impairments and chronic illnesses may have distinct implications for voting.

\section{NOTES}

\footnotetext{
${ }^{1}$ Self-employed persons who are insured under the Self-(PSOR\HG 3HUVRQVII 3HQVLRQV \$FW RU WKH )DUPHUVI Pensions Act are an exception to this rule. For them, the waiting period is only four days.

${ }^{2}$ We repeated the same analyses with the 2012 data using 67 year as the upper limit. The results are practically identical.

${ }^{3}$ Due to privacy reasons, the data set does not include any indicator of the respective electoral ward, thus making clustering or random-effect designs impossible.

${ }^{4}$ On the other hand, if all 12 Sunday dummies are simultaneously included in the same model, the results are somewhat different (the analysis is available from the authors upon request). In that case, the election Sunday dummy variable is the only one with a significant coefficient at the 99 percent confidence level $(b=-0.048$, $\mathrm{p}=0.001$ ). Adding other Sunday dummies only marginally attenuates the coefficient of the election Sunday.
} 
Correspondingly, when controlling for all the 12-day periods, the election period remains significant at the 99 percent level $(\mathrm{b}=-0.037, \mathrm{p}<0.001)$. Only one other period dummy was significant, namely, 36-47 days before elections $(\mathrm{b}=-0.039, \mathrm{p}=0.004)$. Thus, it seems that, when previous health history is controlled for, an illness suffered on the election Sunday could indeed have a small independent negative effect on voting.

${ }^{5}$ We tested interactions between the health variables and socio-economic status variables, but were unable to find any consistent patterns.

${ }^{6}$ However, certain types of chronic health conditions may also have a mobilising effect by activating mechanisms, such as self-interest and social identity (Gollust and Rahn 2015). 


\section{References}

Ansolabehere, S. and Hersh, E. (2012) Validation: what big data reveal about survey misreporting and the real electorate. Political Analysis 20(4): 437-59.

Blais, A. (2000) To vote or not to vote: the merits and limits of rational choice theory. Pittsburgh: University of Pittsburgh Press.

Blomgren, J. (2016) Pitkät sairauspoissaolot työikäisillä naisilla ja miehillä. Sairauspäivärahan saajat 1996-2015. Yhteiskuntapolitiikka 81(6): 681-691.

Brady, H. E., Verba, S. and Schlozman, K. L. (1995) Beyond SES: a resource model of political participation. American Political Science Review 89(2): 271-94.

Braveman, P. and Barclay, C. (2009) Health disparities beginning in childhood: a life-course perspective. Pediatrics 124(supplement 3): 163-75

Bryngelson, A. (2009) Long-term sickness absence and social exclusion. Scandinavian Journal of Public Health 37(8): 839-45.

Burden, B.C., Fletcher, J.M., Herd P., Moynihan D.P. and Jones, B.M. (2017) How different forms of health matter to political participation. Journal of Politics, 79(1);166-78.

Couture, J. and Breux, S. (forthcoming) The differentiated effects of health on political participation. European Journal of Public health, in press.

Dahle, U.R. and Petersen, F.C. (2005) Long term sickness absence: motivation rather than ability to work may be key. BMJ 330(7499): 1087.

Denny, K. and Doyle, O. (2007a) Analysing the relationship between voter turnout and health in Ireland. Irish Medical Journal 100(8): 56-8.

Denny, K. and Doyle, O. (2007b) \$7DNH XS WK\EHG DQG YRW\&dstring the relationship between voting behavior and indicators of health. European Journal of Public Health 17(4): $400-1$. 
Drivsholm, T., Eplov, L. F., Davidsen, M., Jørgensen, T., Ibsen, H., Hollnagel, H. and BorchJohnsen, K. (2006) Representativeness in population-based studies: a detailed description of non-response in a Danish cohort study. Scandinavian Journal of Public Health 34(6): 623-31.

Ferrie, J.E., Vahtera, J., Kivimäki, M., Westerlund, H., Melchior, M., Alexanderson, K., Head, J., Chevalier, A., Leclerc, A., Zins, M., Goldberg, M. and Singh-Manoux, A. (2009) Diagnosisspecific sickness absence and all-cause mortality in the GAZEL study. Journal of Epidemiology and Community Health 63(1): 50-5.

Gastil, J. (2000) The political beliefs and orientations of people with disabilities. Social Science Quarterly 81(2): 588-603.

Gjesdal, S. and Bratberg, E. (2003) Diagnosis and duration of sickness absence as predictors for disability pension: Results from a three-year, multi-register based and prospective study. Scandinavian Journal of Public Health 31(4): 246-254.

Gollust, S.E. and Rahn, W. (2015) The bodies politic: chronic health conditions and voter turnout in the 2008 election. Journal of Health Politics, Policy and Law 40(6): 1115-55.

Henderson, M. and Hillygus, D. Sunshine. (2011) The dynamics of health care opinion, 20082010: partisanship, self-interest, and racial resentment. Journal of Health Politics, Policy and Law 36(6): 945-60.

Jensen, C. and van Kersbergen, K. (2017) The politics of inequality. London: Palgrave Macmillan.

Jylhä, M. (2009) What is self-rated health and why does it predict mortality? Towards a unified conceptual model. Social Science \& Medicine 69(3): 307-16.

Karp, J. A. and Brockington, D. (2005) Social desirability and response validity: a comparative analysis of overreporting voter turnout in five countries. Journal of Politics 67(3): 825-40. 
Kivimäki, M., Forma, P., Wikström, J., Halmeenmäki, T., Pentti, J., Elovainio, M. and Vahtera, J. (2004) Sickness absence as a risk marker of future disability pension: the 10-town study. Journal of Epidemiology and Community Health 58(8): 710-11.

Kivimäki, M., Head, J., Ferrie, J.E., Shipley, M.J. and Marmot, M.G. (2003) Sickness absence as a global measure of health: evidence from mortality in the Whitehall II prospective cohort study. BMJ (Clinical research ed.) 327(7411): 364.

Kröger, H., Pakpahan, E. and Hoffman, R. (2015) What causes health inequality? A systematic review on the relative importance of social causation and health selection. European Journal of Public Health 25(6): 951-960.

Laaksonen, M., Kääriä, S.-M., Leino-Arjas, P. and Lahelma, E. (2011) Different domains of health functioning as predictors of sickness absence-a prospective cohort study. Scandinavian journal of work, environment \& health 37(3): 213-18.

Labriola, M. and Lund, T. (2007) Self-reported sickness absence as a risk marker of future disability pension. Prospective findings from the DWECS/DREAM study 1990-2004. International Journal of Medical Sciences 4(3): 153-58.

Labriola, M., Lund, T. and Burr, H. (2006) Prospective study of physical and psychosocial risk factors for sickness absence. Occupational Medicine 56(7): 469-74.

Lahtinen, H., Mattila, M, Wass H. and Martikainen, P. (forthcoming) Explaining social class inequality in voter turnout: the contribution of money and health. Scandinavian Political Studies, in press.

Martikainen, P., Martikainen, T. and Wass, H. (2005) The effect of socioeconomic factors on voter turnout in Finland: a register-based study of 2.9 million voters. European Journal of Political Research 44(5): 645-69.

Marmot, M., Feeney A., Shipley, M., North, F. and Symc, S.L. (1995) Sickness absence as a measure of health status and functioning: from the UK Whitehall II study. Journal of Epidemiology and Community Health 49(2): 124-30. 
Mattila, M., Söderlund, P., Wass, H. and Rapeli, L. (2013) Healthy voting: the effect of selfreported health on turnout in 30 countries. Electoral Studies 32(4): 886-91.

Mood, C. (2010). Logistic regression: Why we cannot do what we think we can do, and what we can do about it. European sociological review 26(1): 67-82.

OECD (2013) Perceived health status. In Health at a glance 2013: OECD indicators, OECD Publishing. http://dx.doi.org/10.1787/health_glance-2013-13-en, 12.5.2016.

Ojeda, C. (2015) Depression and Political Participation. Social Science Quarterly 96(5): 12261243.

Pacheco, J. and Fletcher, J. (2015) Incorporating health into studies of political behavior: evidence for turnout and partisanship. Political Research Quarterly 68(1): 104-16.

Peterson, S.A. (1987\%LRVRFLDOSUHGLFWRUVRIROGHU \$PHULFDQVIISROLAbIFidOSDUWLFLS and the Life Sciences 5(2): 246-51.

Piha, K. (2013) Socio-economic determinants of sickness absence. Doctoral dissertation. Helsinki: University of Helsinki, Faculty of Medicine, Hjelt Institute, Department of Public Health.

Piha, K., Laaksonen, M., Martikainen, P., Rahkonen, O. and Lahelma, E. (2010) Interrelationships between education, occupational class, income and sickness absence. European Journal of Public Health 20(3): 276-80.

Robert, S. and Booske, B. C. (2011) US opinions on health determinants and social policy as health policy. American Journal of Public Health 101(9): 1655-63.

Schur, L. and Adya, M. (2013) Sidelined or mainstreamed? Political participation and attitudes of people with disabilities in the United States. Social Science Quarterly 94(3): 811-39. 
Schur L. Adya, M. and Mason, A. (2015) Accessible democracy: reducing voting obstacles for people with disabilities. Election Law Journal: Rules, Politics, and Policy 14(1): 60-5.

Schur, L.A. and Kruse, D.L. (2000) What determines voter turnout?, lessons from citizens with disabilities. Social Science Quarterly 81(2): 571-87.

Schur, L., Kruse, D. and Blanck, P. (2013) People with disabilities, sidelined or mainstreamed? Cambridge: Cambridge University Press.

Sciarini, P. and Goldberg A.C. (2016) Turnout bias in postelection surveys: Political involvement, survey participation, and vote overreporting. Journal of Survey Statistics and Methodology 4(1): 110-137.

Smets, K. and van Ham, C. (2013) The embarrassment of riches? A meta-analysis of individual-level research on voter turnout. Electoral Studies 32(2): 344-59.

Sund. R., Lahtinen, H., Wass, H., Mattila, M. and Martikainen, P. (2017) How voter turnout varies between different chronic conditions? A population-based register study. Journal of Epidemiology \& Community Health 71(5): 475-479.

Suominen, S., Koskenvuo, K., Sillanmäki, L., Vahtera, J., Korkeila, K., Kivimäki, M., Mattila, K.J., Virtanen, P., Sumanen, M, Rautava, P. and Koskenvuo, M. (2012) Non-response in a nationwide follow-up postal survey in Finland: a register-based mortality analysis of respondents and non-respondents of the Health and Social Support (HeSSup) Study. BMJ Open 2(2): e000657.

Svedberg, P., Ropponen, A., Lichtenstein P. and Alexanderson, K. (2010) Are self-report of disability pension and long-term sickness absence accurate? Comparisons of self-reported interview data with national register data in a Swedish twin cohort. BMC Public Health, 10(763), online access.

Söderlund, P. and Rapeli, L. (2015) In sickness and in health. Personal health and political participation. Politics and Life Sciences, 34(1): 28-43. 
Vahtera J., Kivimaki M. and Pentti, J. (1997) Effect of organisational downsizing on health of employees. The Lancet 350(9085): 1124-28.

Vahtera, J., Pentti, J. and Kivimäki, M. (2004) Sickness absence as a predictor of mortality among male and female employees. Journal of Epidemiology and Community Health 58(4): $321-26$.

Verba, S., Schlozman, K. Lehman and Brady, H.E. (1995) Voice and equality: civic voluntarism in American politics. Cambridge, MA: Harvard University Press.

Virtanen, P., Siukola, A., Luukkala, T., Savinainen, M., Arola, H., Nygård, C.H., Kivimäki, M., Helenius, H. and Vahtera, J. (2008) Sick leaves in four factories - do characteristics of employees and work conditions explain differences in sickness absence between workplaces? Scandinavian Journal of Work, Environment \& Health 34(4): 260-66.

Voss, M., Floderus, B. and Diderichsen, F. (2004) How do job characteristics, family situation, domestic work, and lifestyle factors relate to sickness absence? A study based on Sweden Post. Journal of Occupational 46(11): 1134-43.

Wass, H., Mattila, M., Rapeli, L. and Söderlund, P. (forthcoming) Voting while ailing? The effect of voter facilitation instruments on health-related differences in turnout. Journal of Elections, Public Opinion and Parties, in press.

Wass, H. and Blais, A. (2017) Turnout. In Kai Arzhaimer, Jocelyne Evans and Michael LewisBeck (eds) SAGE Handbook of electoral behaviour. London: Sage, pp. 459-487.

Wolfinger, R.E. and Rosenstone, S.J. (1980) Who votes? New Haven, CT: Yale University Press.

Young, I.M. (2000) Inclusion and democracy. Oxford: Oxford University Press. 


\section{Tables and figures}

Figure 1. Immediate effect of sickness allowance on voting probability in the 1999 parliamentary elections in Finland. Coefficients from linear probability models with 95 per cent confidence intervals. N: 204532

Sickness allowance on the election Sunday and preceding Sundays (election Sunday=0)

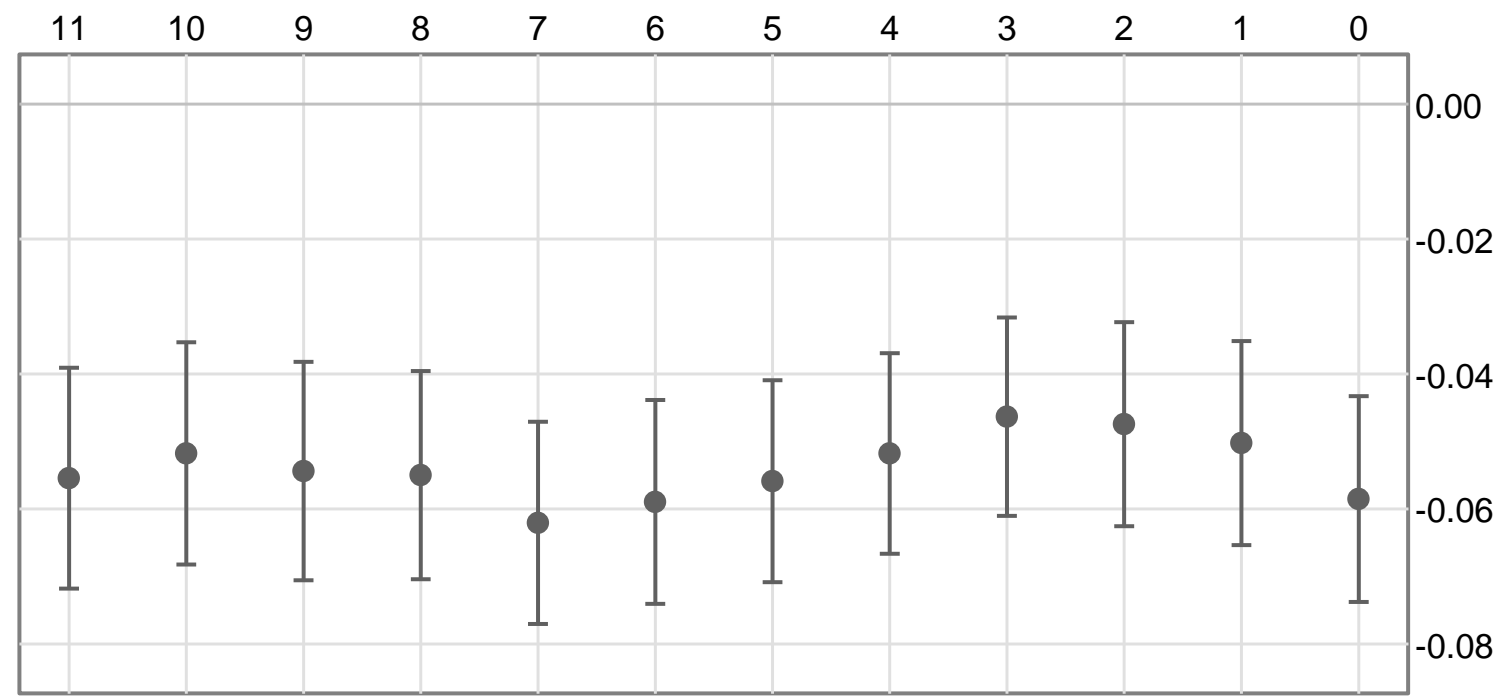

Sickness allowance in 12-day periods preceding elections

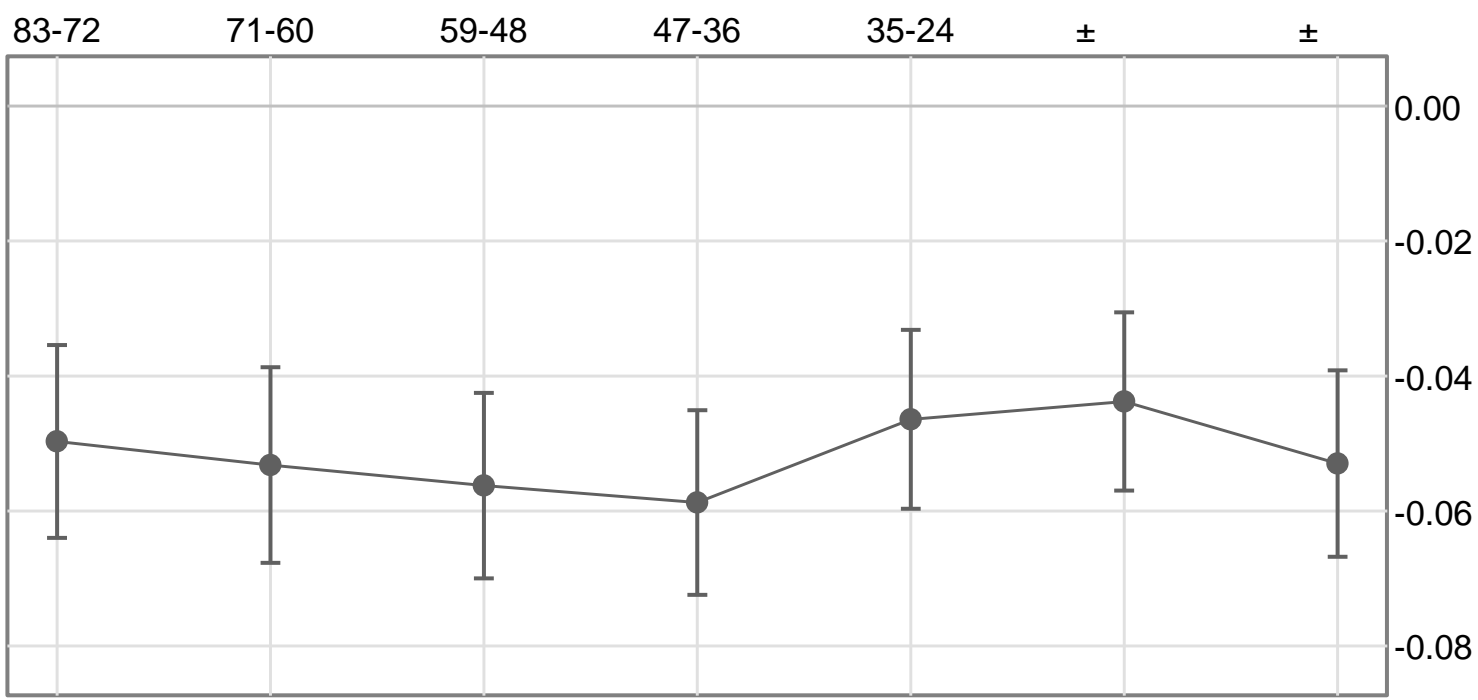

Note: Each point is based on a different model. Each model included age, age ${ }^{2}$ and gender in addition to a dummy variable denoting the Sunday or a 12-day period in question. Those without sickness allowance are the reference group. 
Table 1. The effect of sickness allowances on turnout (linear probability model, OLS regression with robust standard errors in parentheses).

\begin{tabular}{|c|c|c|c|c|c|c|c|c|c|}
\hline \multirow{2}{*}{ 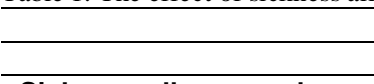 } & \multicolumn{3}{|c|}{ Parliamentary elections 1999} & \multicolumn{3}{|c|}{ Presidential elections 2012} & \multicolumn{3}{|c|}{ Municipal elections 2012} \\
\hline & Model 1 & Model 2 & Model 3 & Model 1 & Model 2 & Model 3 & Model 1 & Model 2 & Model 3 \\
\hline \multicolumn{10}{|l|}{$\begin{array}{l}\text { Sickness allowance days } \\
\text { during previous year }\end{array}$} \\
\hline 17 & $\begin{array}{c}-0.040^{* *} \\
(0.005)\end{array}$ & $\begin{array}{l}-0.011 \\
(0.006)\end{array}$ & $\begin{array}{l}-0.011^{*} \\
(0.006)\end{array}$ & $\begin{array}{l}-0.018 \\
(0.019)\end{array}$ & $\begin{array}{c}0.027 \\
(0.021)\end{array}$ & $\begin{array}{c}0.028 \\
(0.020)\end{array}$ & $\begin{array}{l}-0.028 \\
(0.015)\end{array}$ & $\begin{array}{c}0.009 \\
(0.016)\end{array}$ & $\begin{array}{c}0.012 \\
(0.016)\end{array}$ \\
\hline 830 & $\begin{array}{c}-0.033^{* *} \\
(0.005)\end{array}$ & $\begin{array}{l}-0.003 \\
(0.005)\end{array}$ & $\begin{array}{l}-0.002 \\
(0.005)\end{array}$ & $\begin{array}{c}-0.050^{* *} \\
(0.017)\end{array}$ & $\begin{array}{l}-0.004 \\
(0.018)\end{array}$ & $\begin{array}{l}-0.007 \\
(0.018)\end{array}$ & $\begin{array}{c}-0.055^{\star *} \\
(0.013)\end{array}$ & $\begin{array}{l}-0.014 \\
(0.015)\end{array}$ & $\begin{array}{l}-0.011 \\
(0.014)\end{array}$ \\
\hline 3190 & $-0.050^{* *}$ & $-0.017^{\star}$ & -0.011 & $-0.047^{*}$ & 0.004 & 0.006 & $-0.032^{*}$ & 0.014 & 0.018 \\
\hline & $(0.006)$ & $(0.007)$ & $(0.007)$ & $(0.021)$ & $(0.022)$ & $(0.022)$ & $(0.016)$ & $(0.018)$ & $(0.018)$ \\
\hline 91300 & $\begin{array}{c}-0.074^{* *} \\
(0.010)\end{array}$ & $\begin{array}{c}-0.036^{\star *} \\
(0.011)\end{array}$ & $\begin{array}{l}-0.024^{*} \\
(0.010)\end{array}$ & $\begin{array}{l}-0.087^{* *} \\
(0.031)\end{array}$ & $\begin{array}{l}-0.026 \\
(0.033)\end{array}$ & $\begin{array}{l}-0.009 \\
(0.032)\end{array}$ & $\begin{array}{l}-0.085^{\star *} \\
(0.023)\end{array}$ & $\begin{array}{l}-0.032 \\
(0.024)\end{array}$ & $\begin{array}{l}-0.003 \\
(0.024)\end{array}$ \\
\hline $\begin{array}{l}\text { Nr. of years with sickness } \\
\text { allowance (past } 4 \text { yrs) }\end{array}$ & 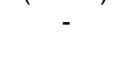 & $\begin{array}{c}-0.021^{* *} \\
(0.002)\end{array}$ & $\begin{array}{l}-0.005^{\star *} \\
(0.002)\end{array}$ & - & $\begin{array}{c}-0.034^{* *} \\
(0.002)\end{array}$ & $\begin{array}{l}-0.016^{\star *} \\
(0.006)\end{array}$ & - & $\begin{array}{c}-0.028^{* *} \\
(0.005)\end{array}$ & $\begin{array}{l}-0.010^{*} \\
(0.004)\end{array}$ \\
\hline \multicolumn{10}{|l|}{ Education } \\
\hline Secondary & - & - & $\begin{array}{l}0.077^{\star \star} \\
(0.003)\end{array}$ & - & - & $\begin{array}{l}0.095^{\star *} \\
(0.012)\end{array}$ & - & - & $\begin{array}{l}0.100^{* *} \\
(0.008)\end{array}$ \\
\hline Lower tertiary & - & - & $\begin{array}{l}0.142^{\star *} \\
(0.003)\end{array}$ & - & - & $\begin{array}{l}0.181^{\star \star} \\
(0.013)\end{array}$ & - & - & $\begin{array}{l}0.206^{\star \star} \\
(0.010)\end{array}$ \\
\hline Upper tertiary & - & - & $\begin{array}{l}0.185^{\star *} \\
(0.004)\end{array}$ & - & - & $\begin{array}{l}0.238^{* *} \\
(0.015)\end{array}$ & - & - & $\begin{array}{l}0.295^{\star \star} \\
(0.012)\end{array}$ \\
\hline \multicolumn{10}{|l|}{ Occupational class } \\
\hline Lower non-manual & - & - & $\begin{array}{l}0.057^{* *} \\
(0.003)\end{array}$ & - & - & $\begin{array}{l}0.070^{* *} \\
(0.010)\end{array}$ & - & - & $\begin{array}{l}0.071^{* *} \\
(0.007)\end{array}$ \\
\hline Upper non-manual & - & - & $\begin{array}{l}0.092^{\star *} \\
(0.003)\end{array}$ & - & - & $\begin{array}{l}0.097^{* *} \\
(0.012)\end{array}$ & - & - & $\begin{array}{l}0.116^{* \star} \\
(0.010)\end{array}$ \\
\hline Self-employed & - & - & $\begin{array}{l}0.109^{* *} \\
(0.003)\end{array}$ & - & - & $\begin{array}{l}0.086^{* *} \\
(0.012)\end{array}$ & - & - & $\begin{array}{l}0.104^{\star *} \\
(0.010)\end{array}$ \\
\hline \multicolumn{10}{|l|}{ Income quartile } \\
\hline 2. quartile & - & - & $\begin{array}{l}0.023^{\star *} \\
(0.003)\end{array}$ & - & - & $\begin{array}{c}0.012 \\
(0.010)\end{array}$ & - & - & $\begin{array}{l}0.016^{*} \\
(0.008)\end{array}$ \\
\hline 3. quartile & - & - & $\begin{array}{l}0.046^{* *} \\
(0.003)\end{array}$ & - & - & $\begin{array}{l}0.054^{* *} \\
(0.010)\end{array}$ & - & - & $\begin{array}{l}0.047^{\star \star} \\
(0.008)\end{array}$ \\
\hline Highest quartile & - & - & $\begin{array}{l}0.062^{* *} \\
(0.003)\end{array}$ & - & - & $\begin{array}{l}0.057^{* *} \\
(0.011)\end{array}$ & - & - & $\begin{array}{l}0.052^{* *} \\
(0.009)\end{array}$ \\
\hline Female & $\begin{array}{l}0.038^{\star *} \\
(0.002)\end{array}$ & $\begin{array}{l}0.040^{\star \star} \\
(0.002)\end{array}$ & $\begin{array}{l}0.035^{\star *} \\
(0.002)\end{array}$ & $\begin{array}{l}0.067^{\star *} \\
(0.007)\end{array}$ & $\begin{array}{l}0.071^{\star *} \\
(0.007)\end{array}$ & $\begin{array}{l}0.046^{\star \star} \\
(0.007)\end{array}$ & $\begin{array}{l}0.036^{* *} \\
(0.005)\end{array}$ & $\begin{array}{l}0.039^{* *} \\
(0.005)\end{array}$ & $\begin{array}{l}0.008^{\star *} \\
(0.006)\end{array}$ \\
\hline Age & $\begin{array}{l}0.026^{\star *} \\
(0.001)\end{array}$ & $\begin{array}{l}0.026^{\star \star} \\
(0.001)\end{array}$ & $\begin{array}{l}0.014^{\star \star} \\
(0.001)\end{array}$ & $\begin{array}{l}0.027^{* *} \\
(0.002)\end{array}$ & $\begin{array}{l}0.027^{\star *} \\
(0.002)\end{array}$ & $\begin{array}{l}0.010^{\star *} \\
(0.002)\end{array}$ & $\begin{array}{l}0.028^{* *} \\
(0.002)\end{array}$ & $\begin{array}{l}0.029^{\star *} \\
(0.002)\end{array}$ & $\begin{array}{l}0.009^{* *} \\
(0.002)\end{array}$ \\
\hline $\mathrm{Age}^{2}$ & $\begin{array}{c}-0.000^{* *} \\
(0.000)\end{array}$ & $\begin{array}{c}-0.000^{* *} \\
(0.000)\end{array}$ & $\begin{array}{l}0.000^{\star *} \\
(0.000)\end{array}$ & $\begin{array}{l}-0.000^{* *} \\
(0.000)\end{array}$ & $\begin{array}{c}-0.000^{\star *} \\
(0.000)\end{array}$ & $\begin{array}{l}-0.000^{*} \\
(0.000)\end{array}$ & $\begin{array}{c}-0.000^{* *} \\
(0.000)\end{array}$ & $\begin{array}{c}-0.000^{\star *} \\
(0.000)\end{array}$ & $\begin{array}{c}0.000 \\
(0.000)\end{array}$ \\
\hline Constant & $\begin{array}{l}-0.068^{* *} \\
(0.016)\end{array}$ & $\begin{array}{l}-0.072^{\star *} \\
(0.016)\end{array}$ & $\begin{array}{l}-0.005 \\
(0.016)\end{array}$ & $\begin{array}{l}-0.039 \\
(0.044)\end{array}$ & $\begin{array}{l}-0.031 \\
(0.042)\end{array}$ & $\begin{array}{l}0.133^{* *} \\
(0.046)\end{array}$ & $\begin{array}{l}-0.263^{* *} \\
(0.031)\end{array}$ & $\begin{array}{l}-0.289^{* *} \\
(0.032)\end{array}$ & $\begin{array}{l}-0.070^{\star *} \\
(0.033)\end{array}$ \\
\hline $\mathrm{N}$ & 204,034 & 204,034 & 204,034 & 16,170 & 16,170 & 16,170 & 32,768 & 32,768 & 32,768 \\
\hline
\end{tabular}

Notes: Reference categories: sickness allowance days ( 0 days), education (basic), occupational class (manual), income (lowest quartile), sex (male), other variables are continuous. $* *$ p $<0.01, * \mathrm{p}<0.05$. 
